\title{
Telemetry Engineering and Fabrication Alternative Soldering Techniques for CFC Elimination
}

Kansas City Division

R. V. Howard

RECEIVED

AUG 211995

KCP-613-5592

OSTI

Published August 1995

Topical Report

Approved for public release; distribution is unlimited.

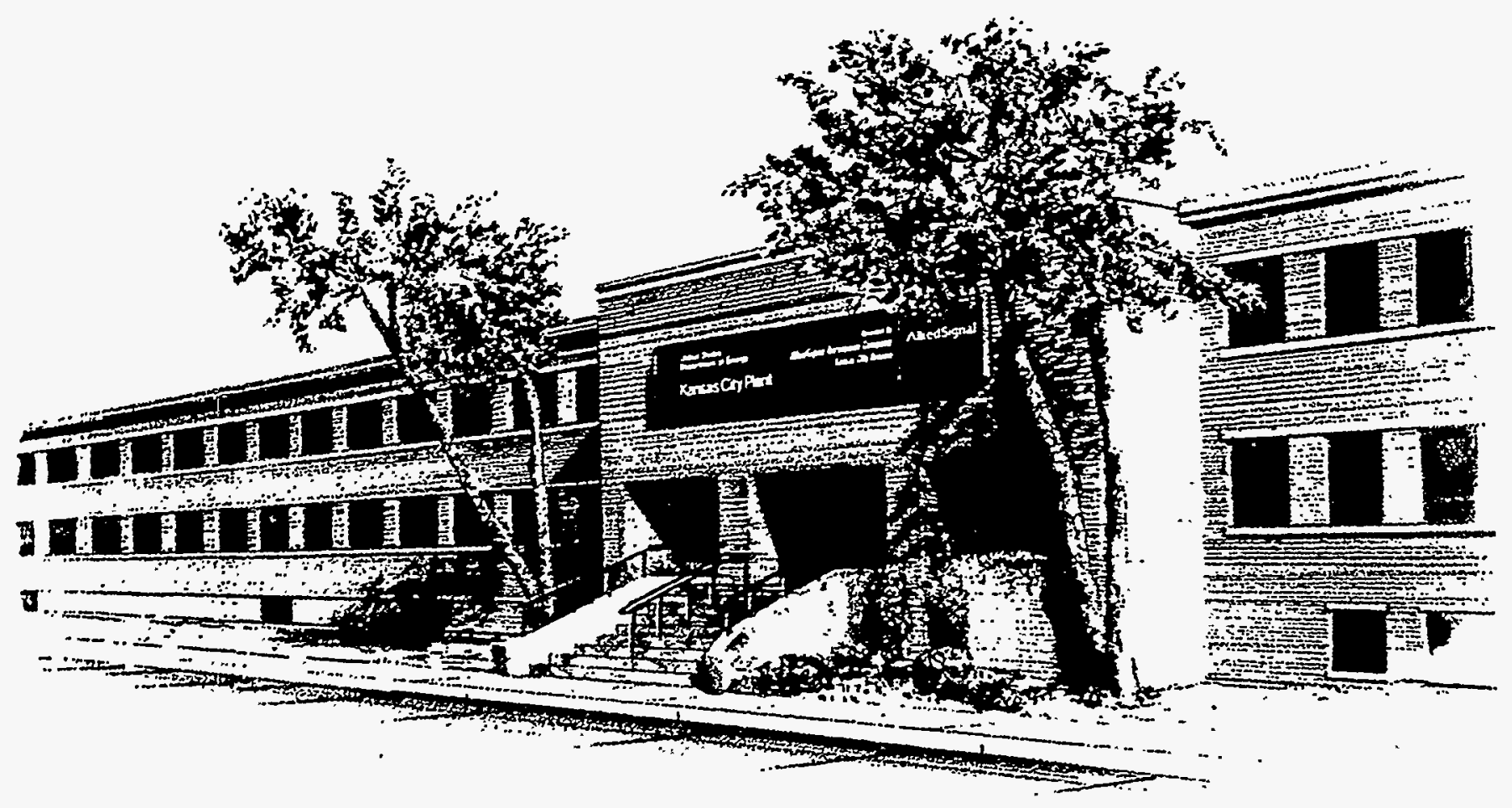

Prepared Under Contract Number DE-ACO4-76-DP00613 for the United States Department of Energy 


\section{DISCLAIMER}

This report was prepared as an account of work sponsored by an agency of the United States Government. Neither the United States Government nor any agency thereof, nor any of their employees, makes any warranty, express or implied, or assumes any legal liability or responsibility for the accuracy, completeness, or usefulness of any information, apparatus, product, or process disclosed, or represents that its use would not infringe privately owned rights. Reference herein to any specific commercial product, process, or service by trade names, trademark, manufacturer, or otherwise, does not necessarily constitute or imply its endorsement, recommendation, or favoring by the United States Government or any agency thereof. The views and opinions of authors expressed herein do not necessarily state or reflect those of the United States Government or any agency thereof.

All data prepared, analyzed and presented has been developed in a specific context of work and was prepared for internal evaluation and use pursuant to that work authorized under the referenced contract. Reference herein to any specific commercial product, process or service by trade name, trademark, manufacturer, or otherwise, does not necessarily constitute or imply its endorsement, recommendation, or favoring by the United States Government, any agency thereof or AlliedSignal Inc.

Printed in the United States of America.

This report has been reproduced from the best available copy.

Available to DOE and DOE contractors from the Office of Scientific and Technical Information, P. O. Box 62, Oak Ridge, Tennessee 37831; prices available from (615) 576-8401, FTS 626-8401.

Available to the public from the National Technical Information Service, U. S. Department of Commerce, 5285 Port Royal Rd., Springfield, Virginia 22161.

A prime contractor with the United States Department of Energy under Contract Number DE-ACO4-76-DP00613.
AlliedSignal Inc. Kansas City Division P. O. Box 419159 Kansas City, Missouri 64141-6159 


\section{, DISCLAIMER}

Portions of this document may be illegible in electronic image products. Images are produced from the best available original document. 
KCP-613-5592

Distribution Category UC-706

Approved for public release; distribution is unlimited.

\title{
TELEMETRY ENGINEERING AND FABRICATION ALTERNATIVE SOLDERING TECHNIQUES FOR CFC ELIMINATION
}

\author{
R. V. Howard
}

Published August 1995

Topical Report

R. V. Howard, Project Leader

Project Team:

B. A. Blankenship

R. K. Creed

K. W. Hallgarth

J. A. Mauth

R. L. McKinnie

R. W. Schmitt

\section{DISCLAIMER}

This report was prepared as an account of work sponsored by an agency of the United States Government. Neither the United States Government nor any agency thereof, nor any of their employees, makes any warranty, express or implied, or assumes any legal liability or responsibility for the accuracy, completeness, or usefulness of any information, apparatus, product, or process disclosed, or represents that its use would not infringe privately owned rights. Reference herein to any specific commercial product, process, or service by trade name, trademark, manufacturer, or otherwise does not necessarily constitute or imply its endorsement, recommendation, or favoring by the United States Government or any agency thereof. The views and opinions of authors expressed herein do not necessarily state or reflect those of the United States Government or any agency thereof.

\section{AlliedSignal \\ A E R O P A C E}


㑇: 


\section{Contents}

Section

Page

Abstract ..................................................................................

Summary .............................................................................. 1

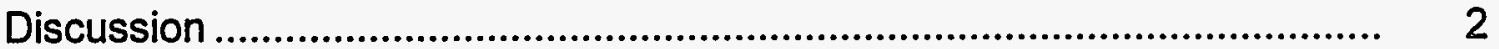

Scope and Purpose ................................................................. $\quad 2$

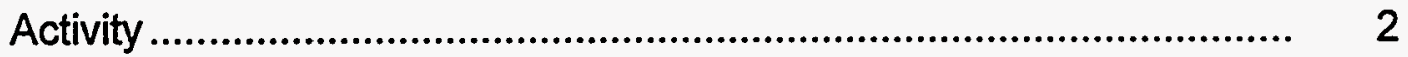

Introduction....................................................................... 2

Experiment 1 ........................................................... 2

Results of Experiment 1 ................................................... 4

Conclusions ................................................................. 8

Accomplishments ........................................................... 8

Future Work................................................................... 9 


\section{Illustrations}

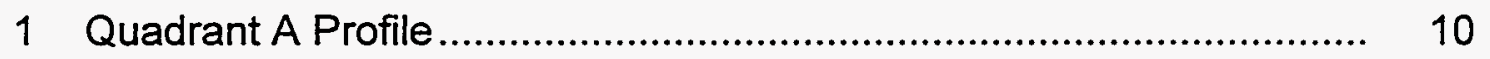

2 Quadrant C Profile ..................................................................... 11

3 Quadrant E Profile ............................................................... 12

4 Quadrant G Profile..................................................................... 13

5 Quadrant J Profile..................................................................... 14

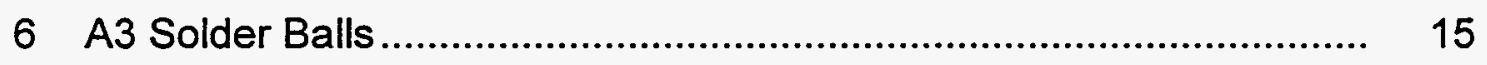

$7 \quad$ A3 C9 Poor Solder Flow ................................................................ 16

8 A3 Backside Overall .................................................................... 17

$9 \quad$ J1 Good Reflow J-Lead ............................................................... 18

10 J2 Good Reflow Chip Caps ........................................................ 19

11 C1 Topside Overall...................................................................... 20

12 C4 Good LCC Cross Section ....................................................... 21

13 C4 Good J-Lead Cross Section....................................................... 21

14 A4 Void J-Lead Cross Section................................................... 22

15 Oven Repeatability Data................................................................. 23

16 Cooling Zone Profile ..................................................................... 25 


\section{Tables}

Number

Page

1 Convection Oven Qualification Matrix ............................................. 3

2 Parameters for Four Corner Quadrants......................................... 3

3 Visual Inspection Results for Qualification Matrix............................ 4

4 Qualification Push and Shear Data Results .................................... 5

5 Convection Oven Qualification Push Data Results............................ 6

6 Maximum Shear Load (MSL) ........................................................... 7

7 Comparison Between Failure Mode Averages and Processes .......... 7 


\begin{abstract}
In an effort to eliminate the need for chlorinated fluorocarbons (CFCs) for several production assemblies in Telemetry Engineering and Fabrication, an alternate soldering reflow process to replace the current vapor phase system was needed. After analyzing IR, convection, and recovery vapor phase soldering reflow methods, it was discovered that an improved process would result from the implementation of a new convection reflow system. The convection oven reflow method was evaluated by collecting data from visual inspections, shear, push, and cross-section tests on several surface mount devices.
\end{abstract}

\title{
Summary
}

Once the reflow method was decided upon, evaluation of several convection ovens led to the purchase of a Vitronics SMR 800 convection oven. The Vitronics convection oven contains twelve heating and four cooling cells. In qualifying the oven for use on telemetry product, a matrix was developed from the baseline profile established. Reflow temperatures and soak times were varied according to the parameters set forth by each of the quadrants in the matrix. The belt speed and individual zone temperature were also varied to obtain the quadrant parameters.

Several printed wiring assemblies (PWAs) were run through the oven in each of the quadrants. The PWAs were given a visual inspection and sent to the lab for shear, push, and cross-section tests. The results of the shear and push data indicated the convection oven reflow process to be better than the vapor phase reflow system. The matrix also helps determine what quadrant parameters produced the best reflow results. Reflowing product in the $\mathrm{C}, \mathrm{G}$, and $\mathrm{J}$ quadrants (using profiles established in these quadrants) produced favorable results in the visual inspection, shear, push, and cross-section tests. 


\section{Discussion}

\section{Scope and Purpose}

The vapor phase reflow soldering system was initially modified to reduce dependency on chlorinated fluorocarbons (CFCs) by replacing the Genesolv D fluid with SF-2. Further efforts to eliminate all chemicals that are either environmental or health hazards have lead to the research of a new reflow soldering process. Analyzing alternative reflow systems has led to a comparison between vapor phase and convection oven technology for use on telemetry product. Process characterization was done on the convection oven and data was compared to that of the vapor phase. The results of the comparison will aid in the qualification process for the convection oven.

\section{Activity}

\section{Introduction}

In an effort to eliminate the need for CFCs for several production assemblies in Telemetry Engineering and Fabrication, an alternate soldering reflow process to replace the vapor phase system was needed. This replacement was the Vitronics SMR800 convection oven. The convection oven contains 12 heating cells ( 6 upper, 6 lower) and 4 cooling cells ( 2 upper, 2 lower). Compressed air is supplied to each of the cells. This air is circulated inside a chamber (high-pressure gas) within each cell and heated for the heating cells. Small perforations in the heater/diffuser panel of each cell allow the heated air to flow into the chamber where the product is located. The product travels on a conveyor/belt system through the different temperature zones within the oven, ultimately resulting in the product's reflowed condition.

This report addresses the steps taken for qualifying the Vitronics convection oven for use on the telemetry programs.

\section{Experiment 1}

The telemetry programs are the first programs scheduled to use the oven and for which a PC\&C qualification plan has been developed. A matrix was created based on the profile established for use in the qualification tests. The matrix is shown in Table 1. 
Table 1. Convection Oven

Qualification Matrix

\begin{tabular}{cc|c|c|c|}
\multicolumn{4}{c}{} & \multicolumn{3}{c}{ Reflow Temp. } \\
& & -10 & Normal & +10 \\
& $-20 \%$ & A & B & C \\
\cline { 3 - 5 } & & & & \\
\hline Soak & Normal & D & E & F \\
\cline { 3 - 5 } & $+20 \%$ & G & H & J \\
\hline
\end{tabular}

The normal profile is in section $\mathrm{E}$. From this profile, the reflow temperature was varied $+1-10^{\circ} \mathrm{C}$ from the $203^{\circ} \mathrm{C}$ nominal, and the soak time was varied $+1-20 \%$ from the 65 -second nominal. The belt speed of the oven and the individual zone temperatures were varied to obtain the parameters for each quadrant. See Figures $1-5$ for detailed information on the $A, C, E, G$, and $\mathrm{J}$ quadrant profiles. (All figures appear following the text.) The reflow temp and soak time parameters for the four corner quadrants are shown in Table 2.

Table 2. Parameters for Four Corner Quadrants

$\begin{array}{ccc}\text { Quadrant } & \begin{array}{c}\text { Average Reflow } \\ \text { Temperature }\left({ }^{\circ} \mathrm{C}\right)\end{array} & \begin{array}{c}\text { Average Soak Time } \\ \text { (Seconds) }\end{array} \\ \text { A } & 191.3 & 50 \\ \text { C } & 215.5 & 47 \\ \text { G } & 190.8 & 80 \\ \text { J } & 215.1 & 80\end{array}$

The qualification tests started with quadrant $E$. Data was collected from visual inspections, shear, push, and cross-section tests on a variety of components consistent with the programs. The qualification tests then moved into the four corner quadrants $(A, C, G, J)$. The four corner quadrants were selected first to determine how robust the process was. The results of the data from inspection, reflow, push, shear, and cross-section would determine whether the other quadrants $(B, D, F, H)$ would need to be evaluated.

Four different style printed wiring boards (PWBs) were used in each of the corner quadrants. J-Lead components, chip caps, and LCCs were used to populate each of the PWBs. The assembly process used was repeated in each of the quadrants. Prior to any fabrication, the PWBs were spray cleaned with AP-20. All the components were tinned with $63 / 37$ solder and 
cleaned prior to any placement. The chip caps received from the vendor were pretinned and did not need a second tinning. If the printed wiring assembly (PWA) contained back side components, solder paste was applied through a stencil onto the PWA. The components were placed by the pick and place machine and then reflowed. The PWA was cooled and the process was repeated for the top side components. The chip caps and J-Lead components were placed directly into the solder paste and then reflowed. The LCC components were done differently. Solder paste was applied and the PWB was reflowed without the LCC being placed. This created solder bumps on each of the LCC pads. After cooling, flux was applied to each of the solder bumps and the PWA air cured for fifteen minutes. The LCCs were then placed onto the solder bumps and the PWA was reflowed.

\section{Results of Experiment 1}

The PWAs from each of the quadrants were inspected after reflow. The results are listed in Table 3. The PWAs were photographed after reflow to illustrate the individual quadrant characteristics. See Figures 6-11.

Table 3. Visual Inspection Results for Qualification Matrix

BOARD \#

$$
\begin{aligned}
& \text { A1 } \\
& \text { A2 } \\
& \text { A3 } \\
& \text { A4 } \\
& \text { C1 } \\
& \text { C2 } \\
& \text { C3 } \\
& \text { C4 } \\
& \text { G1 } \\
& \text { G2 } \\
& \text { G3 } \\
& \text { G4 } \\
& \text { J1 } \\
& \text { J2 } \\
& \text { J3 } \\
& \text { J4 }
\end{aligned}
$$

COMPONENT TYPES

$$
\begin{gathered}
\text { 1-44 J-Lead, } 35 \text { Chip Caps } \\
\text { 4-44 J-Lead } \\
\text { 1-44 J-Lead, } 36 \text { Chip Caps } \\
\text { 1-44 J-Lead, 4-32 LCC } \\
\text { 4-44 J-Lead, } 7 \text { Chip Caps } \\
\text { 1-44 J-Lead, } 35 \text { Chip Caps } \\
\text { 1-44 J-Lead, 36 Chip Caps } \\
\text { 1-44 J-Lead, 4-32 LCC } \\
\text { 4-44 J-Lead } \\
\text { 1-44 J-Lead, } 35 \text { Chip Caps } \\
\text { 1-44 J-Lead, } 36 \text { Chip Caps } \\
\text { 1-44 J-Lead, 4-32 LCC } \\
\text { 4-44 J-Lead } \\
\text { 1-44 J-Lead, 36 Chip Caps } \\
\text { 1-44 J-Lead, 35 Chip Caps } \\
\text { 1-44 J-Lead, 4-32 LCC }
\end{gathered}
$$

\# OF SOLDER
JOINTS

TYPE OF FAILURE

$\begin{array}{ll}114 & 5 \\ 176 & 0 \\ 116 & 4 \\ 172 & 0 \\ 190 & 0 \\ 114 & 0 \\ 116 & 0 \\ 172 & 0 \\ 176 & 0 \\ 114 & 3 \\ 116 & 0 \\ 172 & 0 \\ 176 & 0 \\ 116 & 0 \\ 114 & 0 \\ 172 & 0\end{array}$

Solder Balls, C24, C33, C41, C10, C9

Solder Balls, C10 , C21, C34; Poor Solder Flow C9

Solder Balls, C35, C10, C24

The failure modes for both the push and shear testing fall into three categories. All tests were performed with the 44-pin J-Lead component. The three categories are

A - Component failure, where the component is damaged, usually cracking in an $X$ fashion across the component. The component leads usually remain attached to the PWB.

B - Solder joint separation, where the component lead is separated from the PWB land or pad at the solder joint.

C - Land/Pad separation, where the land or pad is separated from the PWB and is still attached to the component lead via solder. 
Fifteen PWAs were sent out for push and shear testing. A hole was drilled in the PWB to enable pushing the J-Lead from the bottom for the push test. Table 4 shows the results of the push and shear tests done on the qualification PWAs.

Table 4. Qualification Push and Shear Data Results

PUSH DATA

$\begin{array}{ccccc}\text { MATRIX \& } & \text { COMPONENT } & \text { COMP. } & \text { MAX. TENSILE } & \text { FAILURE } \\ \text { BOARD \# } & \text { TYPE } & \text { DESIGN. } & \text { LOAD (LB) } & \text { MODE }\end{array}$

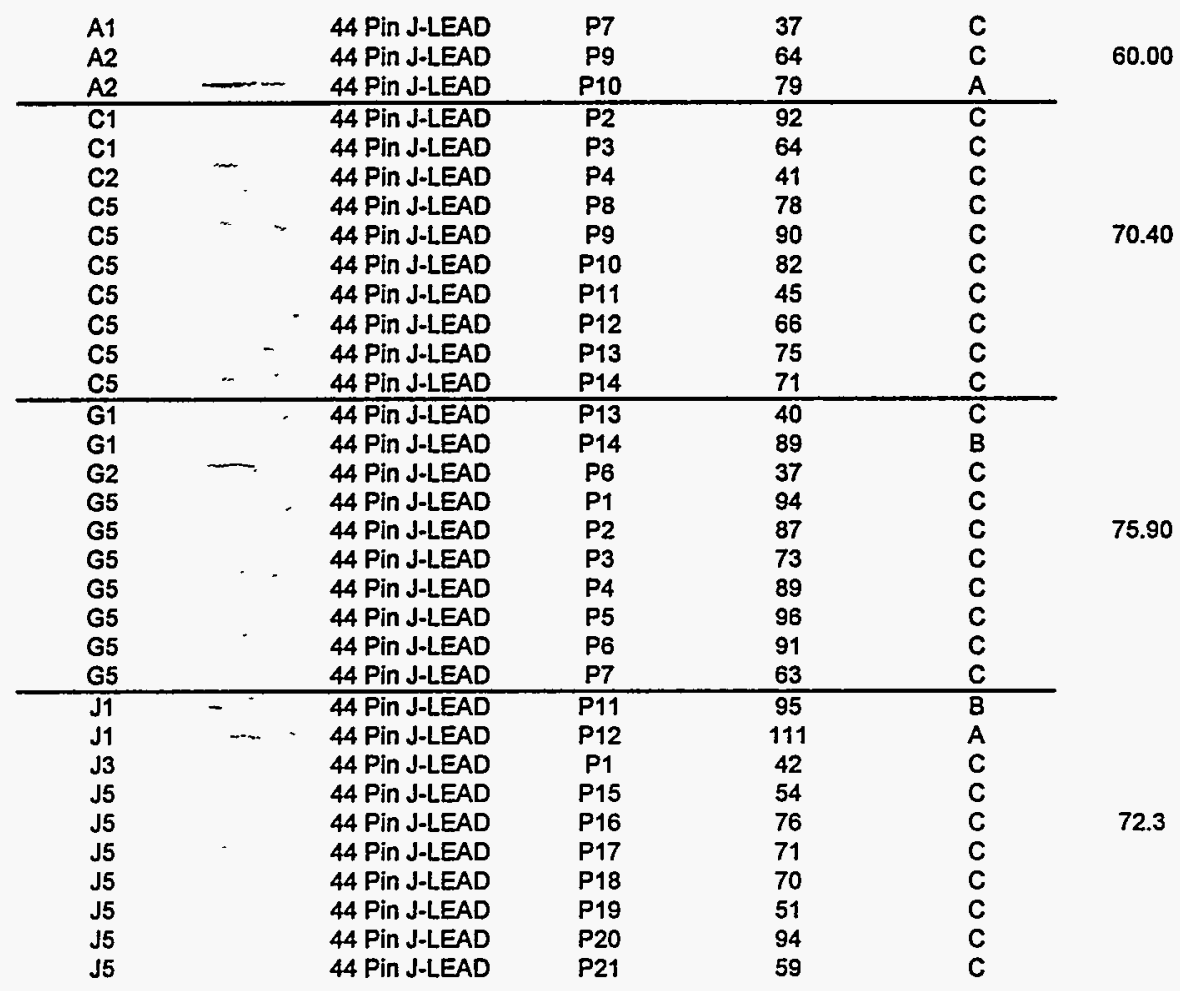

SHEAR DATA

\begin{tabular}{|c|c|c|c|c|c|c|}
\hline $\begin{array}{l}\text { MATRIX \& } \\
\text { BOARD \# }\end{array}$ & & $\begin{array}{c}\text { COMPONENT } \\
\text { TYPE }\end{array}$ & $\begin{array}{l}\text { COMP. } \\
\text { DESIGN. }\end{array}$ & $\begin{array}{l}\text { MAX. TENSILE } \\
\text { LOAD(LB) }\end{array}$ & $\begin{array}{l}\text { FAlLURE } \\
\text { MODE }\end{array}$ & AVERAGE \\
\hline $\begin{array}{l}A 2 \\
A 2 \\
A 3\end{array}$ & & $\begin{array}{l}44 \text { Pin J-LEAD } \\
44 \text { Pin J-LEAD } \\
44 \text { Pin J-LEAD }\end{array}$ & $\begin{array}{l}\$ 9 \\
\$ 10 \\
\$ 7\end{array}$ & $\begin{array}{c}90 \\
\square \\
83\end{array}$ & $\begin{array}{l}\mathrm{B} \\
\mathrm{C} \\
\mathrm{C}\end{array}$ & 86.50 \\
\hline $\begin{array}{l}\text { C1 } \\
\text { C1 } \\
\text { C3 }\end{array}$ & $\cdots$ & $\begin{array}{l}44 \text { Pin J-LEAD } \\
44 \text { Pin J-LEAD } \\
44 \text { Pin J-LEAD }\end{array}$ & $\begin{array}{l}\text { S2 } \\
\text { S3 } \\
\text { S5 }\end{array}$ & $\begin{array}{l}76 \\
81 \\
68\end{array}$ & $\begin{array}{l}\text { B } \\
\text { B } \\
\text { C }\end{array}$ & 75.00 \\
\hline $\begin{array}{l}\mathbf{G 1} \\
\mathbf{G 1} \\
\mathbf{G 3}\end{array}$ & & $\begin{array}{l}44 \text { Pin J-LEAD } \\
44 \text { Pin J-LEAD } \\
44 \text { Pin J-LEAD }\end{array}$ & $\begin{array}{l}\text { S13 } \\
\text { S14 } \\
\text { S6 }\end{array}$ & $\begin{array}{l}72 \\
77 \\
74\end{array}$ & $\begin{array}{l}\text { C } \\
\text { B } \\
\text { C }\end{array}$ & 74.33 \\
\hline $\begin{array}{l}\mathrm{J} 1 \\
\mathrm{~J} 2\end{array}$ & & $\begin{array}{l}44 \text { Pin J-LEAD } \\
44 \text { Pin J-LEAD }\end{array}$ & $\begin{array}{l}\text { S11 } \\
\text { S1 }\end{array}$ & $\begin{array}{r}87 \\
55 \\
\text { NO DATA }\end{array}$ & $\begin{array}{l}\text { B } \\
\text { C }\end{array}$ & 71.00 \\
\hline
\end{tabular}


A PWB was loaded with seven 44-pin J-Lead devices and reflowed with the vapor phase. The PWA had the same three types of push failures associated with it as the other evaluation PWAs. Comparing the average of the three failure modes between the convection oven and the vapor phase yields data results that are very close.

Table 5 is a list of the convection oven push data results broken down by the different mode failure types.

Table 5. Convection Oven Qualification Push Data Results (By mode failure type)

\begin{tabular}{|c|c|c|c|}
\hline $\begin{array}{l}\text { MATRIX \& } \\
\text { BOARD \# }\end{array}$ & $\begin{array}{l}\text { MODE B } \\
\text { COMP. } \\
\text { DESIGN }\end{array}$ & $\begin{array}{l}\text { FAILURE ANALYSIS } \\
\text { MAX. TENSILE } \\
\text { LOAD(LB) }\end{array}$ & AVERAGE \\
\hline G1 & P14 & 89 & 89 \\
\hline J1 & P11 & 95 & 95 \\
\hline & TOTAL & 184 & 92.00 \\
\hline $\begin{array}{l}\text { MATRIX \& } \\
\text { BOARD \# }\end{array}$ & \multicolumn{2}{|c|}{$\begin{array}{cc}\text { MODE C FAILURE ANALYSIS } \\
\text { COMP. } & \text { MAX. TENSILE } \\
\text { DESIGN } & \text { LOAD(LB) }\end{array}$} & AVERAGE \\
\hline$\overline{A I}$ & P7 & 37 & 50.50 \\
\hline $\mathrm{A} 2$ & Pg & 64 & \\
\hline $\mathrm{C}_{1}$ & P2 & 92 & \\
\hline C1 & P3 & 64 & \\
\hline $\mathrm{C} 2$ & P4 & 41 & \\
\hline C5 & P8 & 78 & \\
\hline C5 & P9 & 90 & 70.40 \\
\hline C5 & P10 & 82 & \\
\hline C5 & P11 & 45 & \\
\hline C5 & P12 & 66 & \\
\hline C5 & P13 & 75 & \\
\hline C5 & P14 & 71 & \\
\hline E1 & P22 & 47 & \\
\hline E2 & P23 & 44 & \\
\hline E3 & P24 & 45 & 39.83 \\
\hline$E 4$ & P25 & 40 & \\
\hline E5 & P26 & 27 & \\
\hline E6 & P27 & 36 & \\
\hline G1 & P13 & 40 & \\
\hline G2 & P6 & 37 & \\
\hline G5 & P1 & 94 & \\
\hline G5 & P2 & 87 & \\
\hline G5 & P3 & 73 & 74.44 \\
\hline G5 & P4 & 89 & \\
\hline G5 & P5 & 96 & \\
\hline G5 & P6 & 91 & \\
\hline G5 & P7 & 63 & \\
\hline$\sqrt{3}$ & $P 1$ & 42 & \\
\hline J5 & P15 & 54 & \\
\hline$J 5$ & P16 & 76 & \\
\hline J5 & P17 & 71 & 64.63 \\
\hline J5 & P18 & 70 & \\
\hline J5 & P19 & 51 & \\
\hline $\mathrm{J5}$ & P20 & 94 & \\
\hline $\mathrm{J} 5$ & P21 & 59 & \\
\hline
\end{tabular}

\begin{tabular}{cccc}
$\begin{array}{c}\text { MODE A FAILURE ANALYSIS } \\
\text { MATRIX \& } \\
\text { BOARD \# }\end{array}$ & $\begin{array}{c}\text { COMP. } \\
\text { DESIGN }\end{array}$ & $\begin{array}{c}\text { MAX. TENSILE } \\
\text { LOAD(LB) }\end{array}$ & AVERAGE \\
\hline A2 & P10 & 79 & 79 \\
\hline J1 & P12 & 111 & 111 \\
\hline & TOTAL & 190 & 95.00
\end{tabular}

MODE C FAIL ANAL MATRIX \& COMP. MAX. TENSILE AVERAGE BOARD \# DESIGN LOAD(LB)

\begin{tabular}{llll}
\hline A2 & P9 & 64 & 64.00 \\
\hline C1 & P2 & 92 & \\
C1 & P3 & 64 & \\
C5 & P8 & 78 & \\
C5 & P9 & 90 & 73.67 \\
C5 & P10 & 82 & \\
C5 & P11 & 45 & \\
C5 & P12 & 66 & \\
C5 & P13 & 75 & \\
C5 & P14 & 71 & \\
G1 & P13 & 40 & \\
G5 & P1 & 94 & \\
G5 & P2 & 87 & \\
G5 & P3 & 73 & \\
G5 & P4 & 89 & \\
G5 & P5 & 96 & \\
G5 & P6 & 91 & \\
G5 & P7 & 63 & \\
J5 & P15 & 54 & \\
J5 & P16 & 76 & \\
J5 & P17 & 71 & \\
J5 & P18 & 70 & \\
J5 & P19 & 51 & \\
J5 & P20 & 94 & \\
J5 & P21 & 59 & \\
\hline & TOTAL & 1835 & \\
\hline & & & \\
\hline
\end{tabular}


Ninety-five chip caps were sheared off eight PWAs. Forty-eight of those were the large chip caps (1210), and 47 small chip caps (0805) were used in the evaluation. Those failures fall into just two categories ( $B$ and $C$ ) as mentioned earlier. Summarizing that data yields the results shown in Table 6.

Table 6. Maximum Shear Load (MSL)

\begin{tabular}{|c|c|c|c|c|c|c|c|c|c|c|c|}
\hline \multirow[b]{2}{*}{$\begin{array}{c}\text { MATRIX \& } \\
\text { BOARD \# } \\
\text { A1 }\end{array}$} & \multirow[b]{2}{*}{$\begin{array}{c}\text { CAP \# } \\
1 \\
2 \\
3\end{array}$} & \multirow[b]{2}{*}{$\begin{array}{c}\text { MSL (L) } \\
23.50 \\
36.50 \\
35.50\end{array}$} & \multirow[b]{2}{*}{$\begin{array}{c}\text { LAR } \\
\text { AVER. } \\
\text { MSL (L) } \\
31.80\end{array}$} & \multirow[b]{2}{*}{$\begin{array}{c}\text { GE CHIP } \\
\text { MSL (S) } \\
25.00 \\
28.50 \\
24.50\end{array}$} & \multirow[b]{2}{*}{$\begin{array}{l}\text { AAPS } \\
\text { AVER. } \\
\text { MSL (S) } \\
26.00\end{array}$} & \multirow[b]{2}{*}{$\begin{array}{c}\text { FAILURE } \\
\text { MODE } \\
\text { B }\end{array}$} & \multirow[b]{2}{*}{$\begin{array}{c}\text { MSL (L) } \\
10.00 \\
10.00 \\
11.40\end{array}$} & \multirow[b]{2}{*}{$\begin{array}{l}\text { SMAL } \\
\text { AVER. } \\
\text { MSL (L) } \\
10.50\end{array}$} & \multirow[b]{2}{*}{$\begin{array}{c}\text { CHIP CA } \\
\text { MSL (S) } \\
11.20 \\
9.40 \\
10.60\end{array}$} & \multirow[b]{2}{*}{$\begin{array}{l}\text { APS } \\
\text { AVER. } \\
\text { MSL (S) } \\
10.40\end{array}$} & \multirow[b]{2}{*}{$\begin{array}{l}\text { FAILURE } \\
\text { MODE } \\
\text { B+C }\end{array}$} \\
\hline & & & & & & & & & & & \\
\hline A3 & $\begin{array}{l}1 \\
2 \\
3\end{array}$ & $\begin{array}{l}28.50 \\
31.50 \\
32.00\end{array}$ & 30.70 & $\begin{array}{l}26.50 \\
23.00 \\
29.50\end{array}$ & 26.30 & $B+C$ & $\begin{array}{c}7.70 \\
11.20 \\
\text { no data }\end{array}$ & 9.40 & $\begin{array}{l}11.50 \\
12.30 \\
11.60\end{array}$ & 11.80 & $B+C$ \\
\hline $\mathrm{C2}$ & $\begin{array}{l}1 \\
2 \\
3\end{array}$ & $\begin{array}{l}23.00 \\
24.00 \\
24.00\end{array}$ & 27.50 & $\begin{array}{l}22.50 \\
21.50 \\
27.00\end{array}$ & 23.70 & B & $\begin{array}{l}7.40 \\
7.00 \\
8.50\end{array}$ & 7.60 & $\begin{array}{c}3.50 \\
9.50 \\
10.90\end{array}$ & 8.00 & B \\
\hline C3 & $\begin{array}{l}1 \\
2 \\
3\end{array}$ & $\begin{array}{l}31.50 \\
21.00 \\
27.00\end{array}$ & 26.50 & $\begin{array}{l}23.50 \\
26.50 \\
21.00\end{array}$ & 23.70 & B & $\begin{array}{c}6.80 \\
12.50 \\
9.00\end{array}$ & 9.40 & $\begin{array}{c}12.60 \\
11.40 \\
9.10\end{array}$ & 11.00 & $B+C$ \\
\hline $\mathbf{G 2}$ & $\begin{array}{l}1 \\
2 \\
3\end{array}$ & $\begin{array}{l}19.00 \\
26.50 \\
29.50\end{array}$ & 25.00 & $\begin{array}{l}20.00 \\
24.50 \\
21.50\end{array}$ & 22.00 & B & $\begin{array}{c}17.20 \\
9.60 \\
9.40\end{array}$ & 12.10 & $\begin{array}{l}13.80 \\
10.60 \\
10.80\end{array}$ & 11.70 & B \\
\hline G3 & $\begin{array}{l}1 \\
2 \\
3\end{array}$ & $\begin{array}{l}21.00 \\
29.00 \\
24.50\end{array}$ & 24.80 & $\begin{array}{l}24.00 \\
26.00 \\
28.50\end{array}$ & 26.20 & B & $\begin{array}{l}7.80 \\
9.30 \\
9.50\end{array}$ & 8.90 & $\begin{array}{l}12.60 \\
13.90 \\
10.70\end{array}$ & 12.40 & B \\
\hline$\sqrt{2}$ & $\begin{array}{l}1 \\
2 \\
3\end{array}$ & $\begin{array}{l}25.50 \\
51.30 \\
33.00\end{array}$ & 36.60 & $\begin{array}{l}22.00 \\
23.00 \\
19.00\end{array}$ & 21.30 & B & $\begin{array}{l}6.60 \\
9.60 \\
8.70\end{array}$ & 8.30 & $\begin{array}{l}10.00 \\
10.00 \\
12.60\end{array}$ & 10.80 & B \\
\hline J3 & $\begin{array}{l}1 \\
2 \\
3\end{array}$ & $\begin{array}{l}20.50 \\
32.50 \\
25.50\end{array}$ & 26.20 & $\begin{array}{l}24.50 \\
30.00 \\
20.50\end{array}$ & 25.00 & B & $\begin{array}{c}10.00 \\
13.40 \\
9.70\end{array}$ & 11.00 & $\begin{array}{c}9.50 \\
9.40 \\
12.10\end{array}$ & 10.30 & $B+C$ \\
\hline
\end{tabular}

(L) = push against long edge, (S) = push against short edge

Failure mode $C$ (land/pad separation) was the most common in this evaluation. It attributed to $90 \%$ of the failures out of 39 pushed components. In summarizing this data, a pattern developed on a particular style of PWB. The PWA push data were consistently lower than current and previous push data results. All of the PWBs were manufactured out of plant and of the same lot. The vendor quality of the PWB was in question after analyzing the low results of the mode $C$ failures. Delivery of the PWBs from the vendor was in an unusually expedient fashion.

The average for each of the failure modes between the two processes for push data is listed in Table 7. 
Table 7. Comparison Between Failure Mode Averages and Processes

\begin{tabular}{ccc} 
Failure Mode & Convection Oven & Vapor Phase \\
A & 95 & 93 \\
B & 92 & 88 \\
C & 64 & 63 \\
\multicolumn{2}{c}{ Readings are maximum tensile load (Ib). }
\end{tabular}

Four PWAs were sent to the lab for cross-sectioning tests. Two LCCs and one J-Lead device were cross-sectioned out of each corner quadrant. The joints were cross-sectioned and photographed at 40X power, checking for voids, non-wetting, etc. All eight of the LCC joints looked good with no voids or other solder defects present. On one of the four J-Lead joints cross-sectioned, a small void of approximately two mils in diameter is present close to the end of the " $\mathrm{J}$ " in the upswing area. The void is small in comparison to the overall 68-mil J-Lead solder footprint. The void is on the board that was from the A quadrant. (See Figures 12-14.)

\section{Conclusions}

Evaluation of all the data collected from the experiments performed during the oven process control and characterization shows that the oven is capable of performing as well or better than the vapor phase process used in the telemetry department. The push and shear tests yielded results in the same range as the vapor phase, and the cross section showed that the convection oven process produces fewer voids. The standard profile (profile E) was created before these experiments were performed and is still the suggested profile to use. Even though profile A was the worst performing profile and should not be used; it still reflowed $99 \%$ of the joints on the board, showing that this profile is just on the outside edge of the oven's capability envelope. The other envelope edges are more determined by component environment restrictions, but profiles $\mathrm{C}, \mathrm{G}$, and $\mathrm{J}$ are inside the capability envelope of the oven.

\section{Accomplishments}

The control portion of these experiments consists of calibration and weekly monitoring. The oven temperature sensors were calibrated and are on a periodic calibration cycle through KCD metrology. The weekly monitoring is done using a generic test fixture with four thermocouples mounted to a nickel-plated copper plate. The thermocouples are monitored using the Datapaq which is also calibrated and is on a periodic calibration cycle. Figure 15 shows the data collected to date. Using this system shows the oven to be in good control in the heating zones. The cooling zones have more variation. These zones do not have a way to cool the air, allowing bleed-through from the last heating zone to raise the temperature in the cooling zones. After one hour these zones will stabilize as shown in Figure 16. 


\section{Future Work}

The new business and programs coming to the department that contains surface mount devices will be evaluated and profiled for the convection oven. Product that contains a surface mount device not previously characterized will go through additional PC\&C evaluations. 


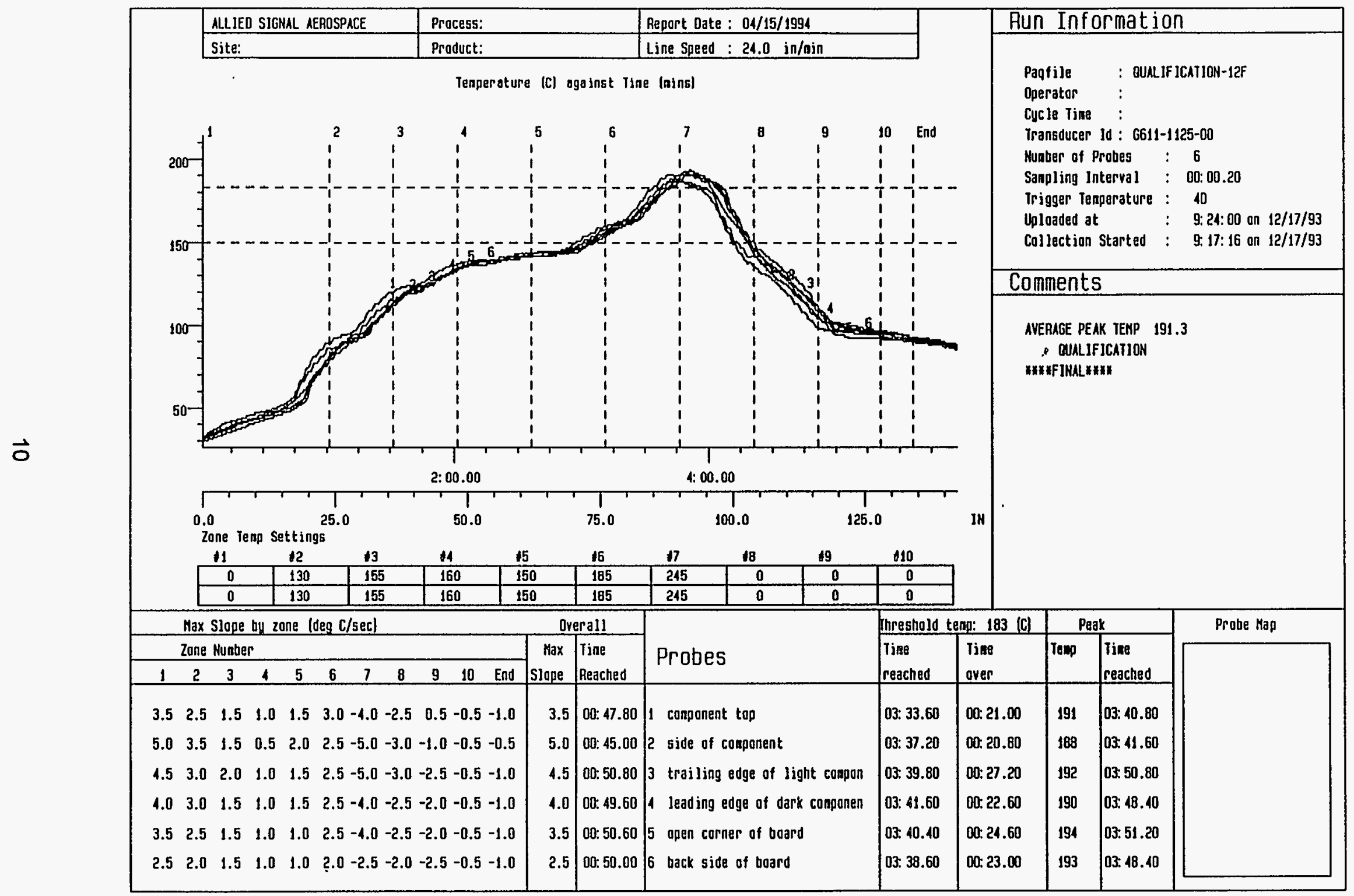

Figure 1. Quadrant A Profile 


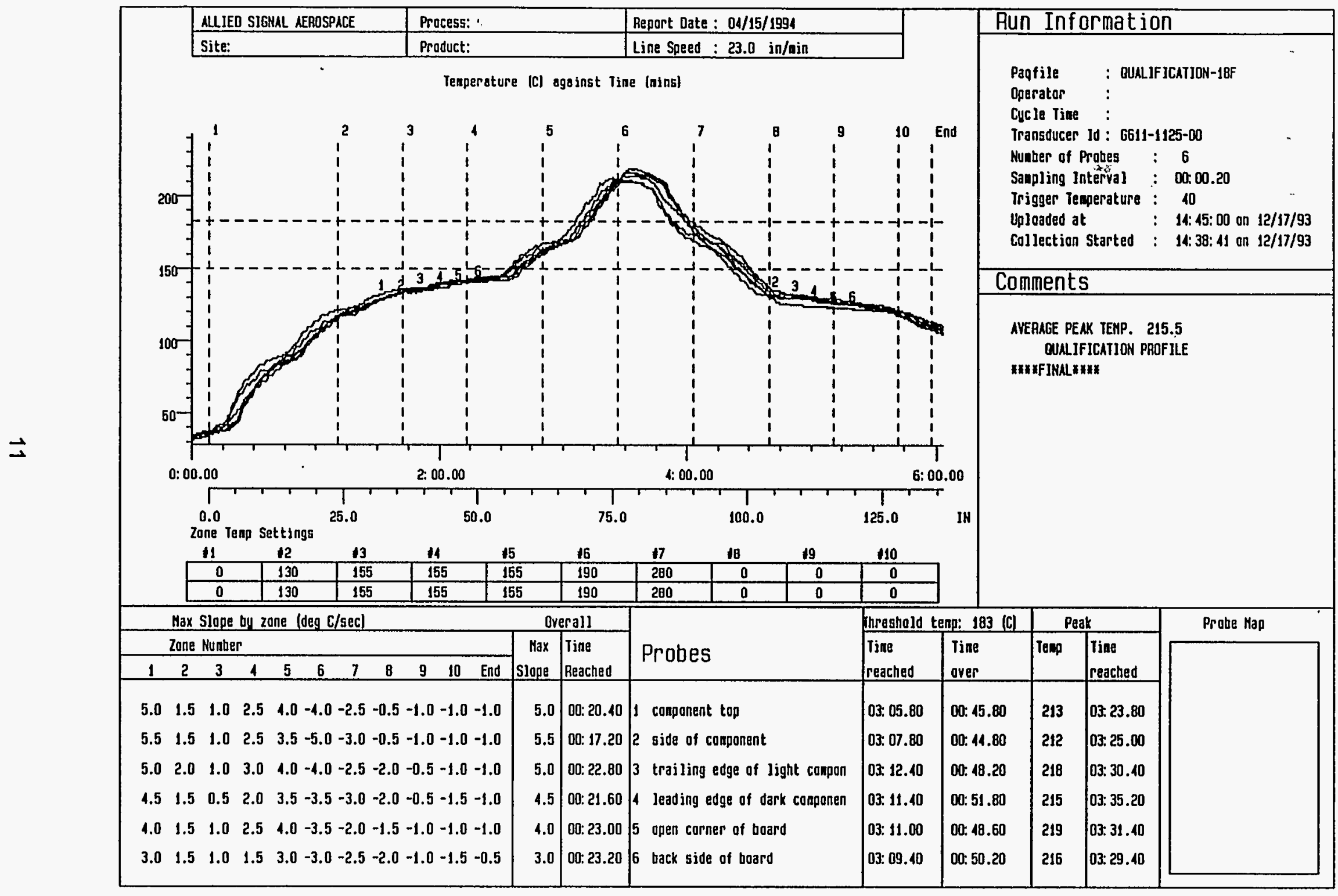

Figure 2. Quadrant C Profile 


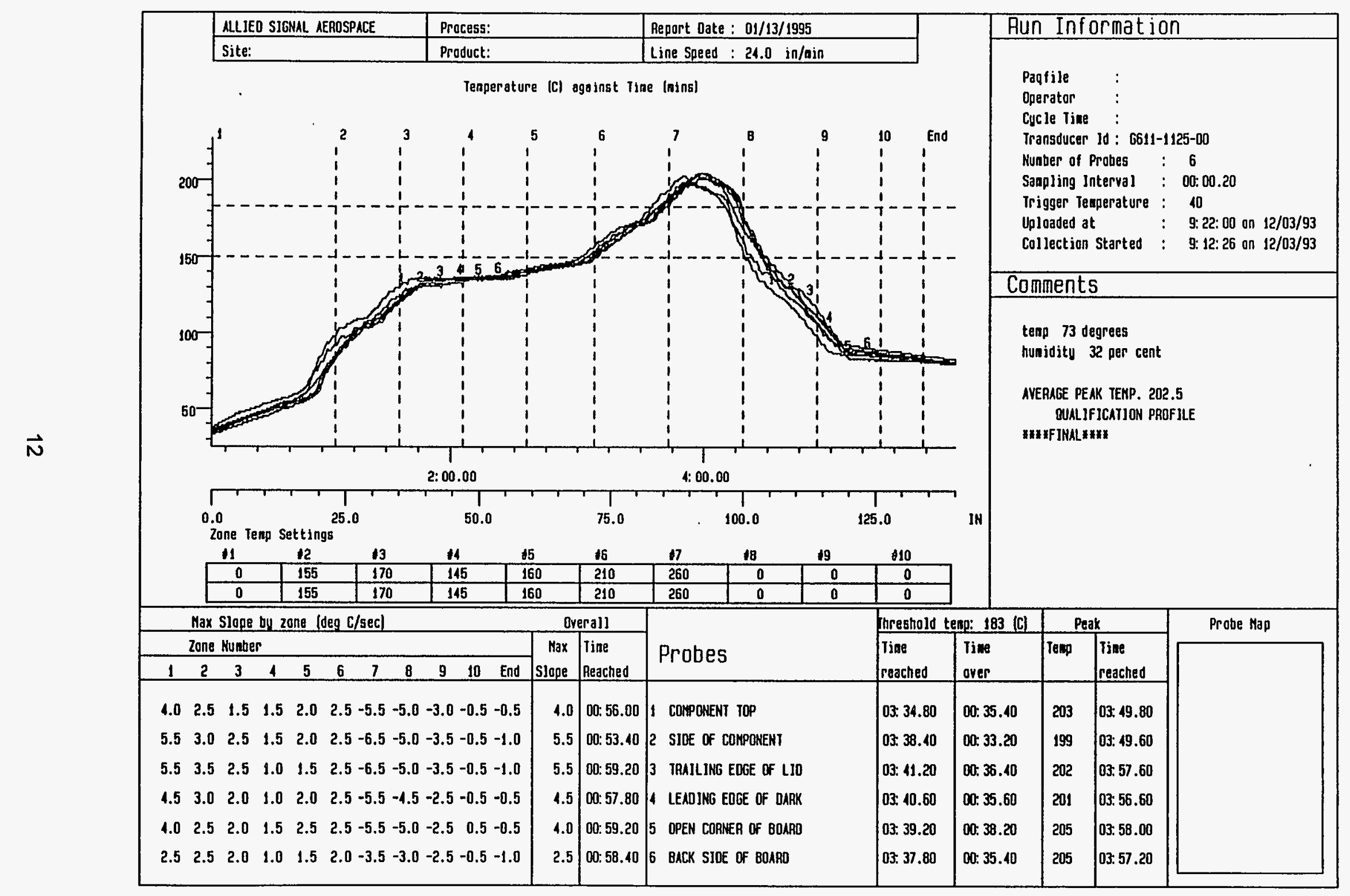

Figure 3. Quadrant E Profile 


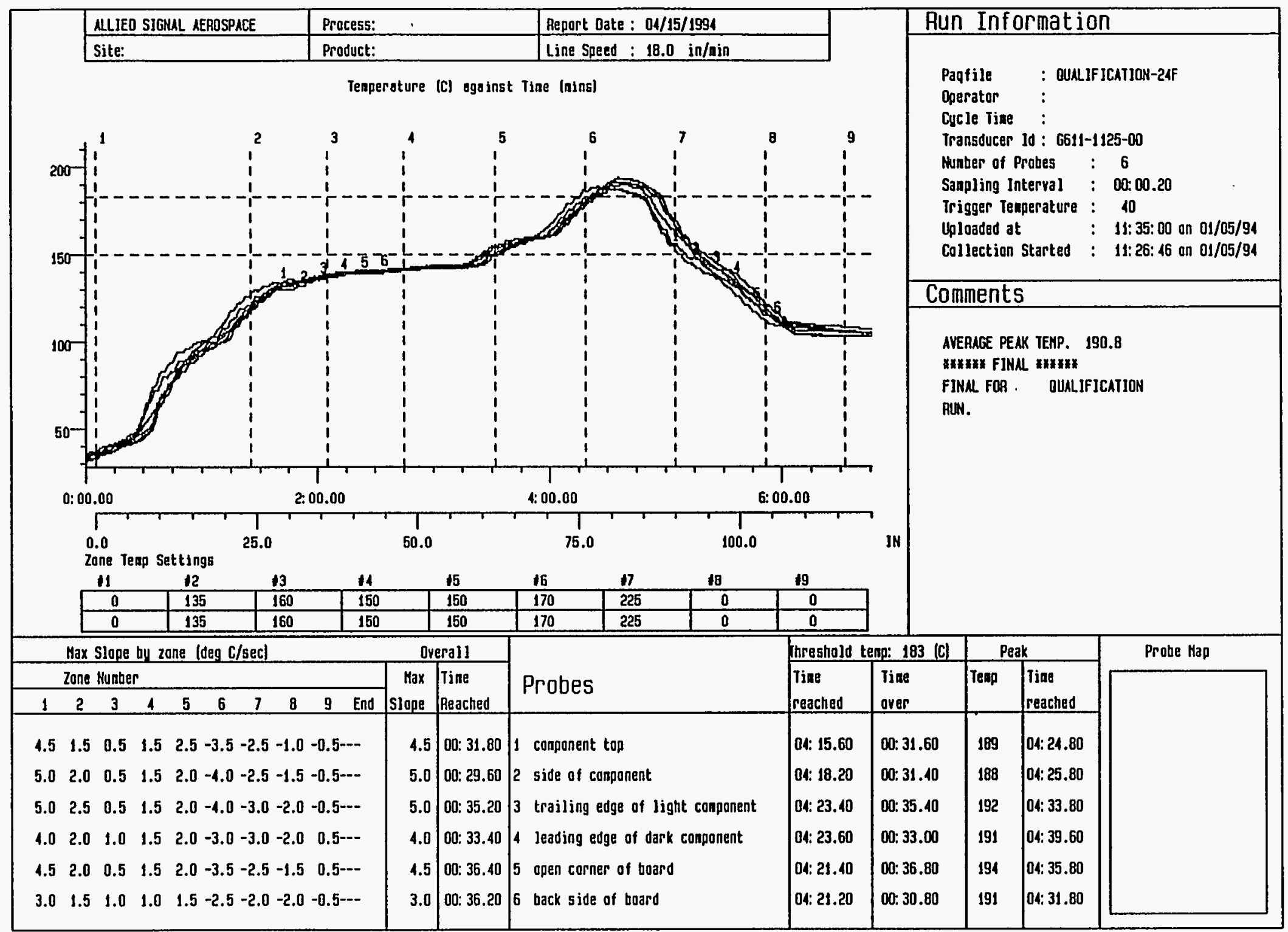

Figure 4. Quadrant G Profile 


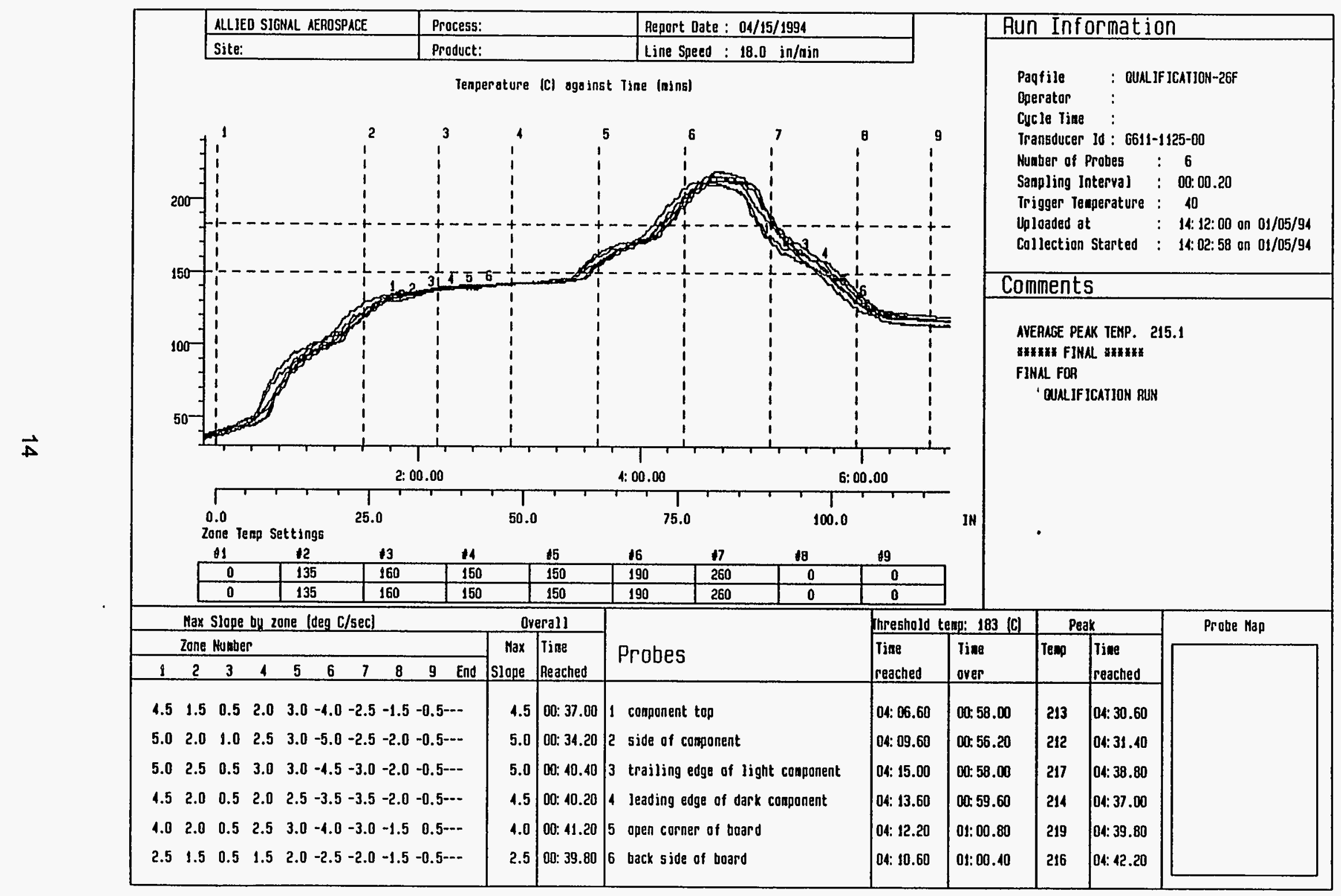

Figure 5. Quadrant J Profile 


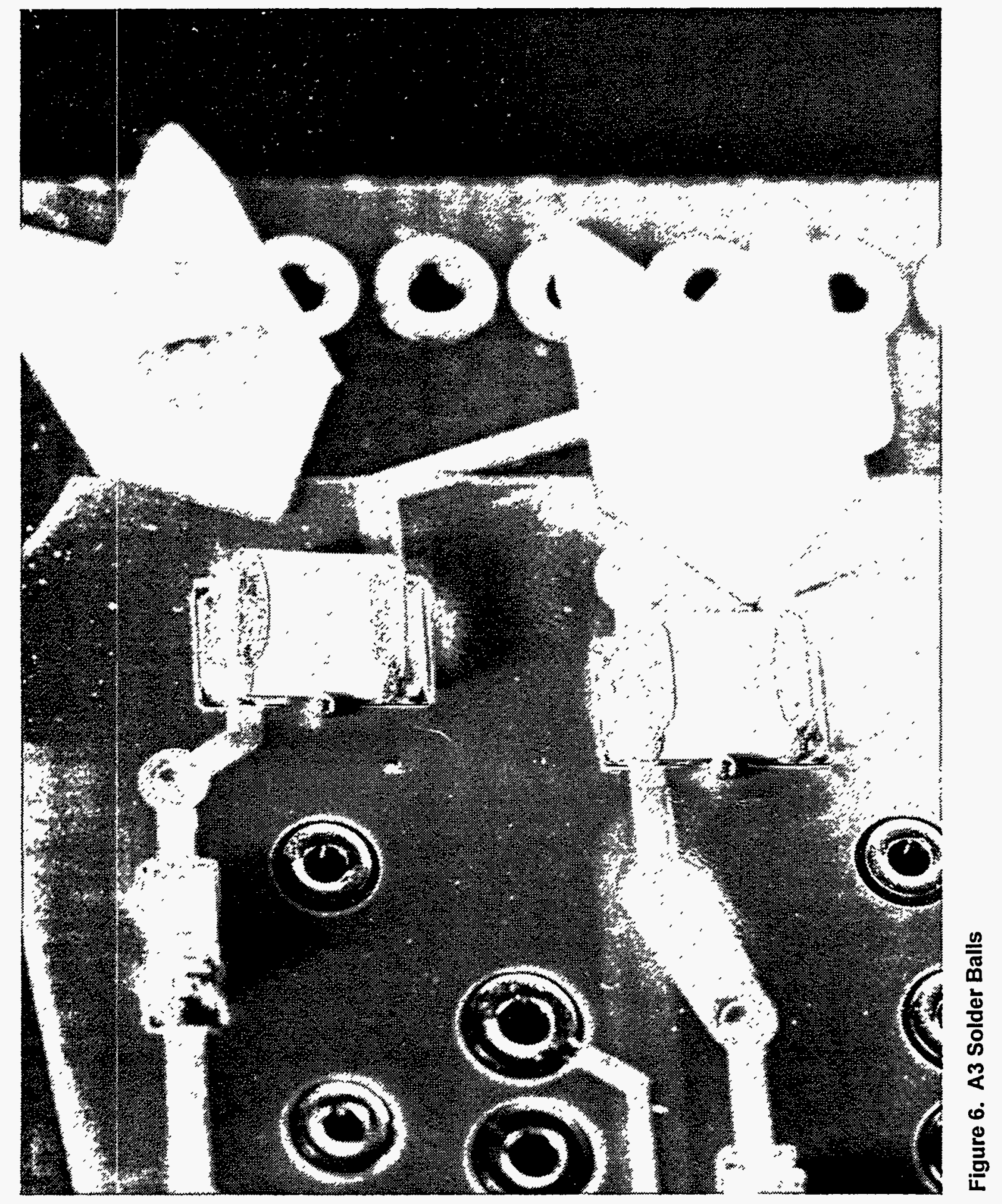




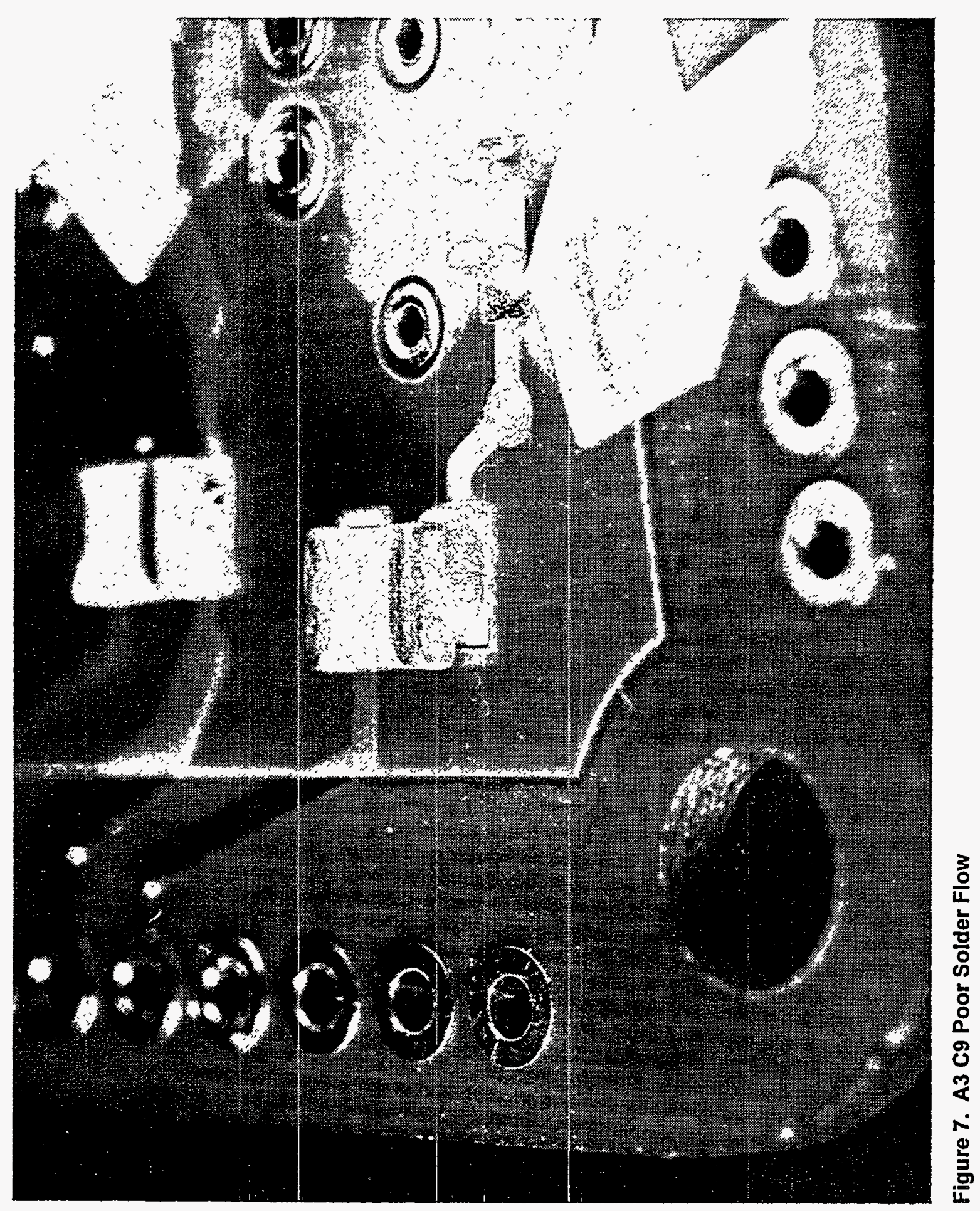




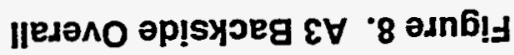

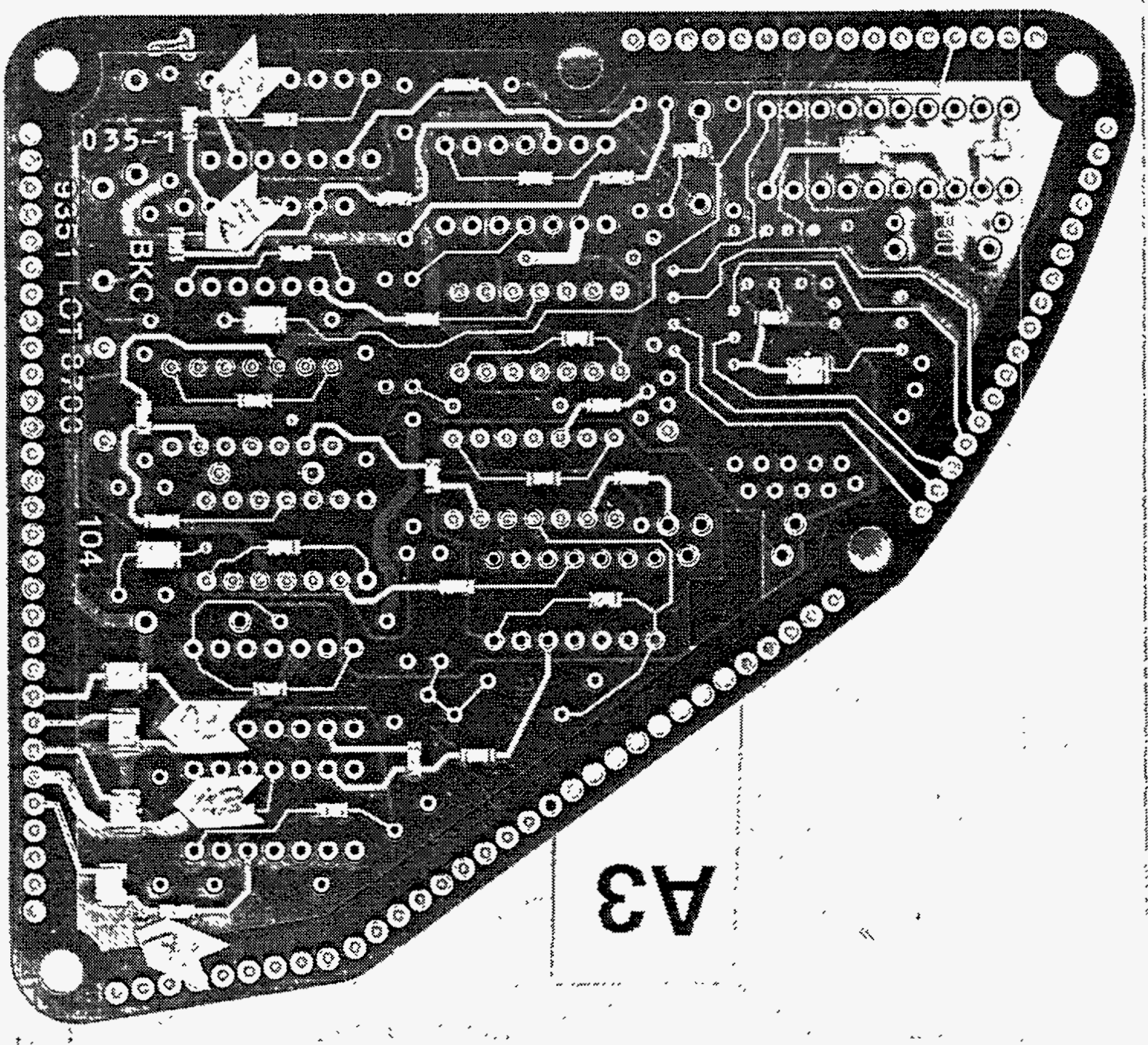




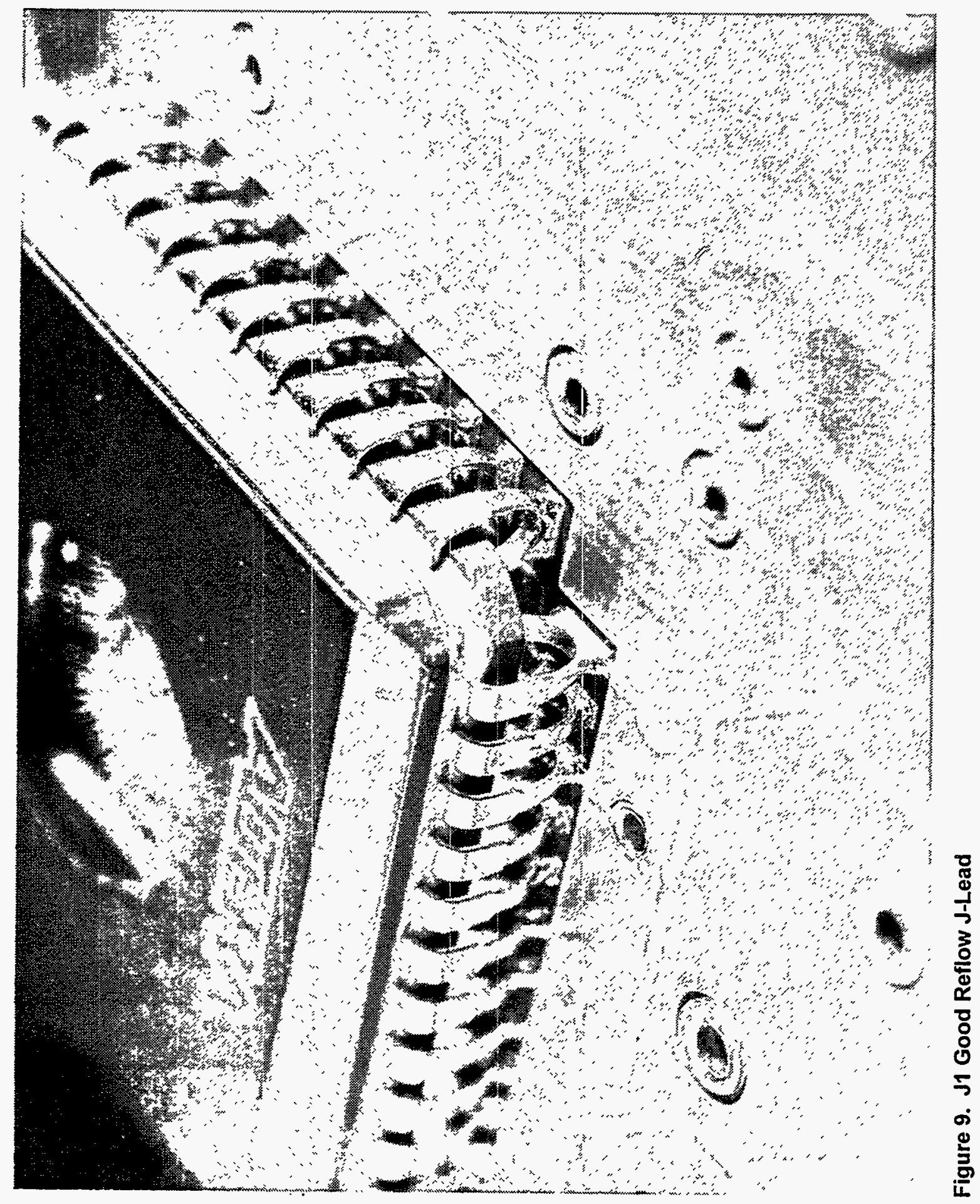




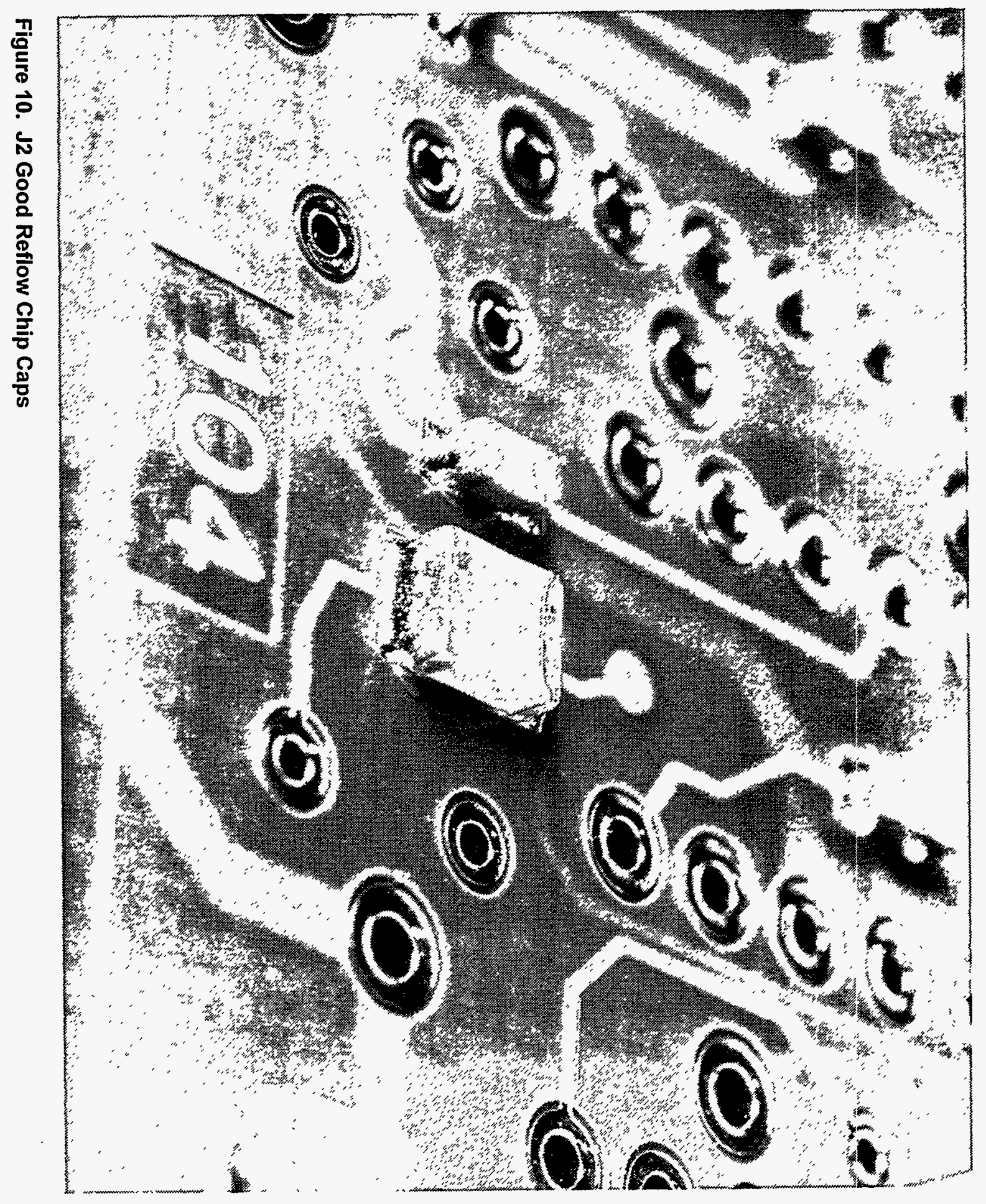




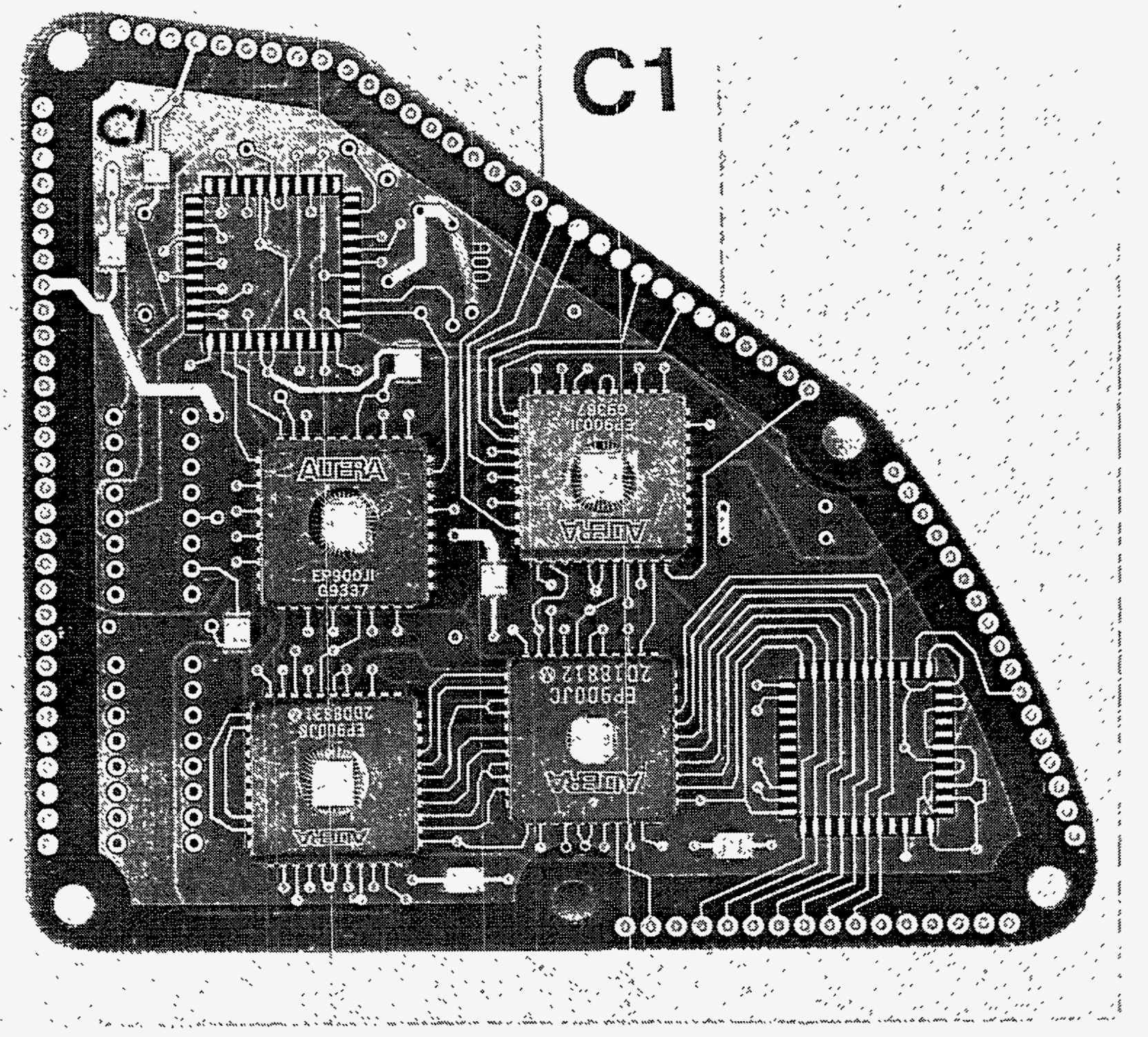

Figure 11. C1 Topside Overall 


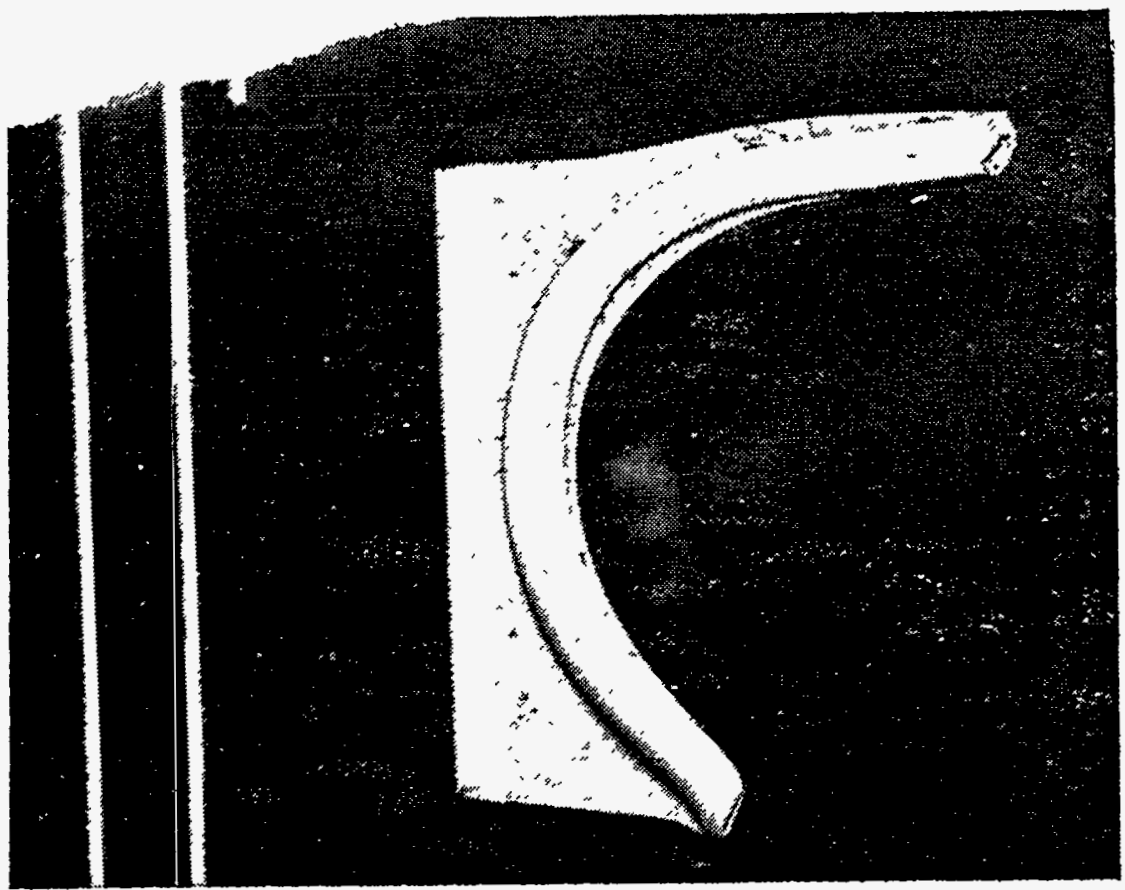

Figure 12. C4 Good LCC Cross Section
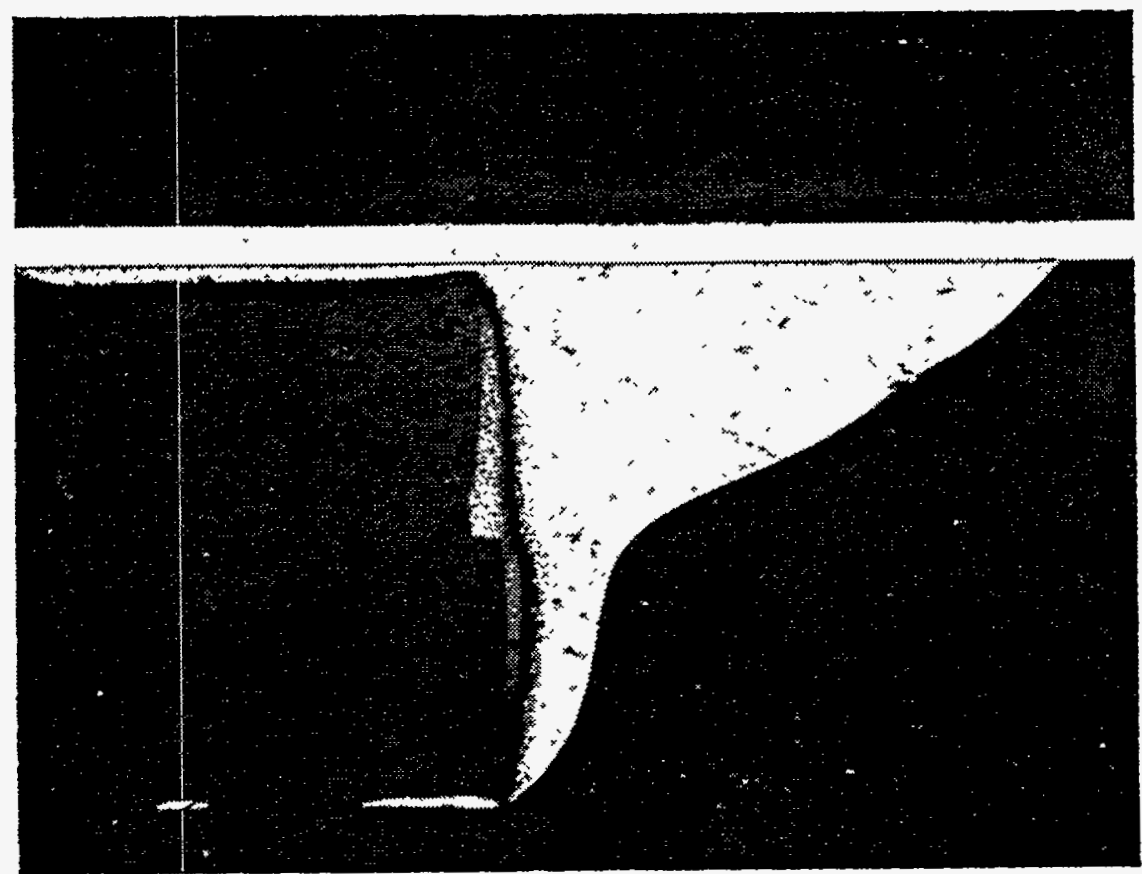

Figure 13. C4 Good J-Lead Cross Section 


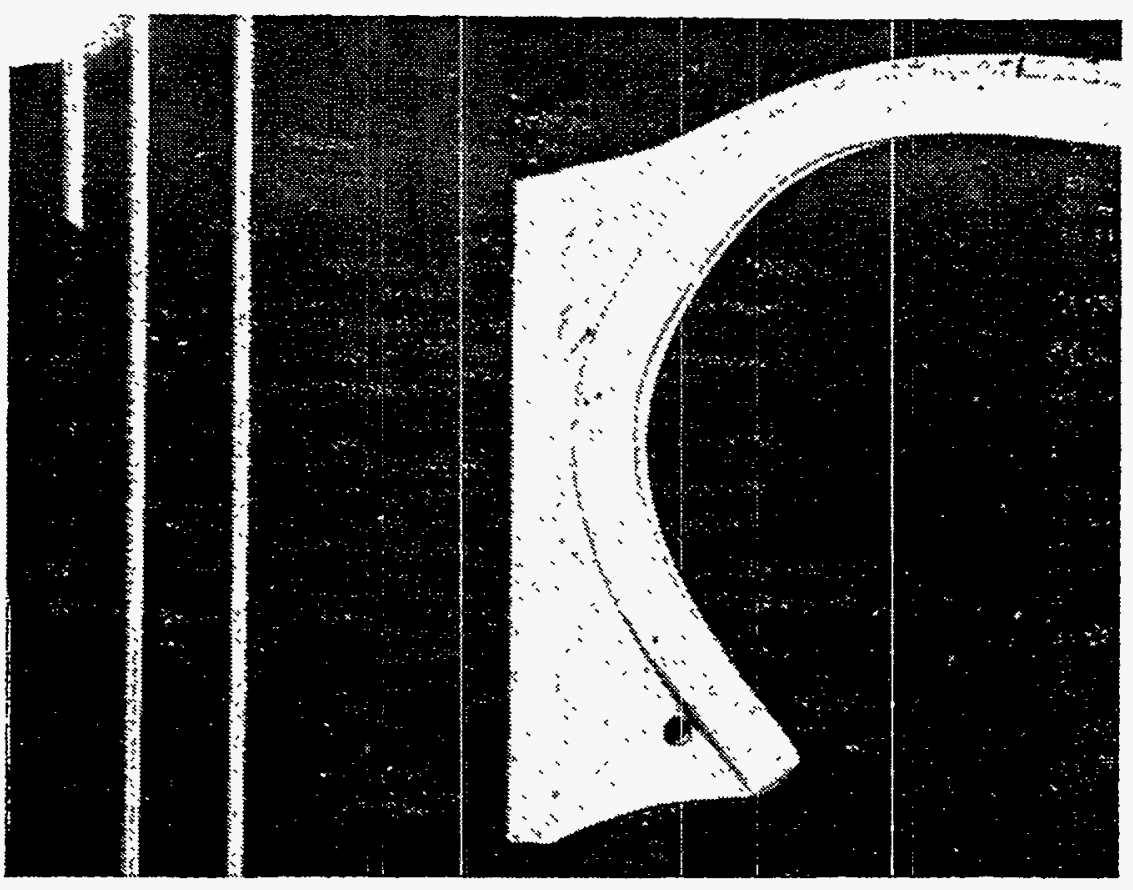

Figure 14. A4 Void J-Lead Cross Section 


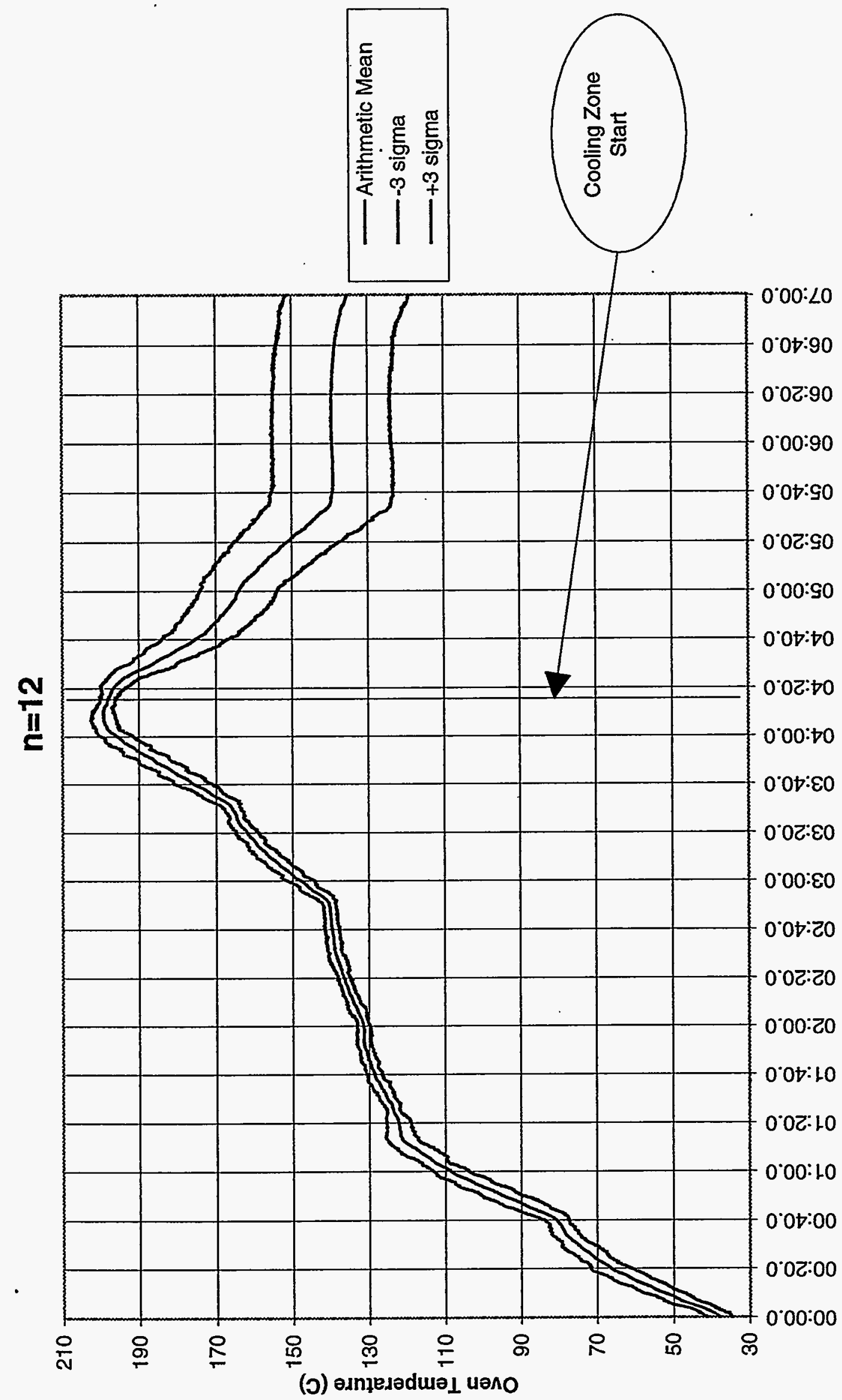

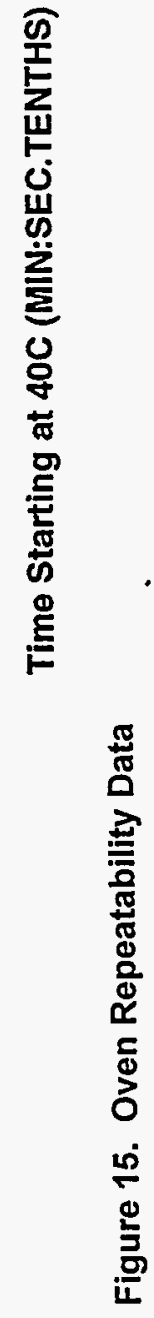


. 


$$
\mathbb{U}_{i}^{\prime}
$$

